\title{
A Test of Treeline Theory on a Montane Permafrost Island
}

\author{
Christian Körner*† and \\ Günter Hoch* \\ *Institute of Botany, University of Basel, \\ Schönbeinstrasse 6, CH-4056 Basel, \\ Switzerland. \\ †Corresponding author. \\ ch.koerner@unibas.ch
}

\begin{abstract}
Trees have a common high elevation distribution limit at similar soil temperatures across the globe. Here we tested whether low temperature in the root zone alone can induce the well known dwarfing at the low temperature growth limit of trees by using a "natural experiment" with trees growing on low elevation permafrost ground. At the natural high elevation treeline, both air (shoot) and soil (root) temperature are low, while at the montane permafrost site in the Swiss Jura mountains, roots are cold, but not shoots. Soil temperature records confirmed that the low elevation study site resembles thermal conditions typical for the high elevation treeline. The warm air conditions have no ameliorating effect on tree growth. Irrespective of shoot temperatures, the root zone temperature and the associated metabolism appear to determine tree growth at this site. The test revealed a critical role of soil temperature, which by itself is sufficient to explain a growth limit of trees associated with a seasonal mean soil temperature at $10 \mathrm{~cm}$ depth of around $6^{\circ} \mathrm{C}$.
\end{abstract}

\section{Introduction}

Climate driven treeline formation at high altitudes is a global phenomenon, paralleling the snowline and following a common growing-season isotherm. Neither season length nor temperature during the dormant season is reflected in global treeline patterns (Körner, 1998; Körner and Paulsen, 2004). A multitude of secondary drivers may modulate the actual treeline position from place to place by processes not considered in this paper, which focuses on thermal limitation.

The high altitude transition from a tall, upright growth form (tree) to low stature, prostrate growth forms (shrub, grass) is not related to particular constraints on tree physiology, but is associated with tree architecture and its interaction with atmospheric convection. Plants growing close to the ground profit from low aerodynamic coupling to ambient conditions and heat up under solar radiation, and during the night, shoot meristems near the surface or in the top soil receive thermal benefits from heat stored in the ground (Wilson et al., 1987; Grace et al., 1989; Körner, 2003). In contrast, upright trees are aerodynamically well coupled to free atmospheric convection, and their shoot meristems experience temperatures very close to ambient air temperature. Closed canopy forests screen solar radiation from the ground, and thus prevent significant soil heat flux. As a consequence, the root zone under trees is always significantly colder than under adjacent low stature alpine vegetation (e.g., Bonan and Shugart, 1989; Körner, 2003). Upright trees thus experience a colder climate than other plant growth forms, once tree saplings emerge from the aerodynamically buffering low stature vegetation. It is well established that growth of shoots and roots of trees is very sensitive to low temperature and commonly ceases below species' specific thresholds, between 5 and $7{ }^{\circ} \mathrm{C}$ (e.g., Tryon and Chapin, 1983; Scott et al., 1987; Bonan and Shugart, 1989; Takenaka and Abaimov, 1998; Karlsson and Nordell, 1996; Häsler et al., 1999; Domisch et al., 2001).

A recent assessment of year-round temperatures at natural treeline elevations indicated a global mean root zone temperature during the growing period (irrespective of its length) of $6.7 \pm 0.8^{\circ} \mathrm{C}$, and this temperature also corresponds closely with the $24 \mathrm{~h}$ mean of air temperature, which shoots are exposed to during this period (Körner and Paulsen, 2004). The surprisingly similar temperature regime at the high altitude treelines worldwide suggests a common cause for their formation. Given that genera as different as Abies, Pinus, Picea, Juniperus, Betula, Alnus, Eucalyptus, Erica, Sorbus, and Polylepis have elevational limits within a similar narrow range of temperatures, the underlying biological mechanism is likely to be similar. Available evidence strongly points toward the old concept of growth (sink) limitation rather than photosynthetic (source) limitation (Däniker, 1923; Bonan and Shugart, 1989; Körner, 1998). In fact, the carbon reserve loading of treeline trees compared to trees grown at a few hundred meters below treeline is not reduced, but can even be significantly increased (Hoch and Körner, 2003), suggesting a low temperature limitation of structural investments of carbon. The compounds stored mostly have high molecular weight, and thus are not osmotically active, and lipids can represent a significant fraction.

Although daily means of air and ground temperature (shoot and root meristems) are similar at treeline, such mean temperatures mask the greater diurnal amplitude of air temperature, i.e., commonly higher during the day and cooler during the night than soil temperature. It is thus uncertain whether soil temperature alone, air temperature alone (e.g., nighttime lows), or a combination of both is critical for tree performance. In this study, we explore these alternatives by making use of a "natural experiment" where trees reach a growth limit at a site, where growing season air temperatures are warm (700-800 m below the climatic treeline), but root temperatures are lower because of pockets of permanent ground ice. Known as "Creux du Van", this natural amphitheater (Fig. 1) in the Jura mountains of western Switzerland has attracted scientists for many years. Early explanations associated the semicircular escarpment with a meteorite impact. Later works suggest a fluvio-glacial origin, common to several of such landscape features in that region (Monbaron, 1990, and references therein). The patches of peculiarly dwarfed Norway spruce (Picea abies) trees inside the "crater" had been associated with permafrost for many years (Richard, 1961) and recent studies by Delaloye and Reynard (2001) and Delaloye et al. (2003) revealed the supporting evidence that ground temperatures are low and are clearly associated with permafrost.

Thus, the formation of permafrost at only ca. $1200 \mathrm{~m}$ elevation at $47^{\circ}$ northern latitude results from a peculiar geological formation, which screens sunlight during much of the dormant season from a steep, poleward-facing slope. Similar locations have been found in other parts of the Jura mountains and the Alps (e.g., in southern Austria 


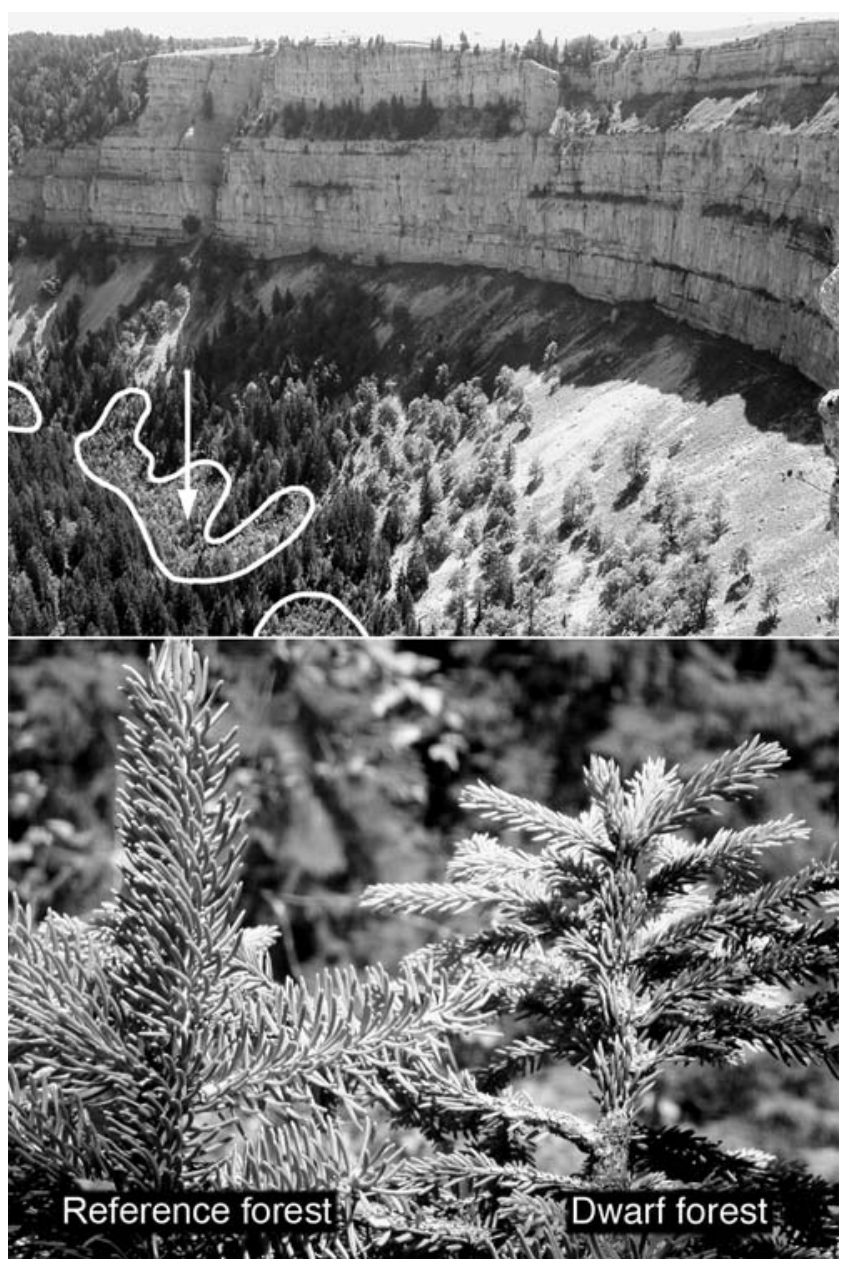

FIGURE 1. The Creux du Van escarpment in the Swiss Jura Mountains with the dwarf tree zones (encircled) at 1190-1220 m elevation. Lower part: reference and dwarfed shoots of Norway spruce (Picea abies). The arrow indicates the location where temperatures were measured in the dwarf tree stand.

[Hölzel, 1963; Schindler et al., 1976; Wegmüller and Wegmüller, 1985], 10 well documented sites in Switzerland [Rist, 2002], and in the Black Forest in Germany [Molenda and Gude, 2000]).

According to the analysis by Delaloye and coworkers, the steeply inclined perennial body of ice of the Creux du Van has a thickness of ca. $15-20 \mathrm{~m}$ and is overlain with $>2 \mathrm{~m}$ of coarse debris and rocks eroded from the escarpment. The rough surface of the block field is covered with a fragmented and thin, very peaty soil and a vegetation of arctic affiliation with Betula pubescens and dwarfed Picea abies trees and a ground cover dominated by Vaccinium myrtillus and mosses (Richard, 1961). The steep block field has many vents through which air can enter or emerge (Fig. 2). In winter, when ambient temperatures are below the temperature of the permafrost, heavier cold air seeps into the base of the block fields and is emitted at its upper end at a comparatively higher temperature, reflecting the ice body's surface conditions. In summer, the circulation is reverted and cold air drains along the ice body's surface and is emitted at downslope vents. Such cold air movements in coarse debris underlain by permafrost have been described in other cases (Schindler et al., 1976; Rist, 2002), and the phenomenon has been known for over a century (Canaval, 1893). This seasonal air circulation system not only contributes to the persistence of the ice lenses but also explains low soil temperatures at the downslope end of the ice body during the growing season. It also explains why drainage of cold air becomes even enhanced when the

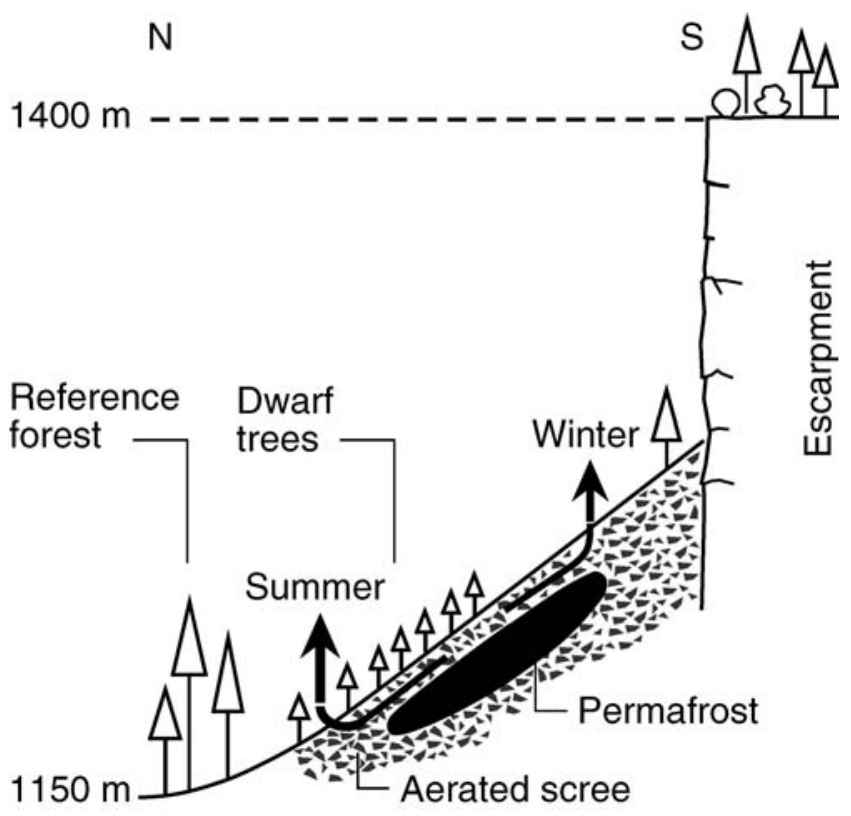

FIGURE 2. A simplified scheme of air circulation through the block fields overlaying the permafrost zone at Creux du Van (following Delaloye et al., 2003).

weather is very hot, because thermal gradients are steeper. Hot summers thus produce the coldest soil temperatures and cool summers produce the least chilling soil conditions. This paradox provides rather peculiar life conditions for plants, with their shoots exposed to high temperatures and their roots exposed to cold temperatures. Given the small diameter of the ice lenses (ca. 30-60 m), tall upright forest and dwarfed forest occur in adjacent stands with a very sharp transition, permitting a comparison of temperatures and growth under otherwise similar conditions.

We hypothesized that the dwarfed trees are growing under soil temperatures that resemble treeline situations and that the dwarfing is solely driven by the root zone temperature. We have no reason to assume different thermal limitations for basic metabolic processes in shoots and roots, particularly in their meristems. Thus, our second hypothesis is that once one part of the tree is growth-limited by low temperature, in this case the roots, higher temperatures of other parts (shoots) have no compensatory effect. In order to test these hypotheses, we measured root zone and air temperature in both dwarfed and reference trees and document the effect of the different temperature regimes on tree growth by using simple biometric measures and tree rings.

\section{Methods}

\section{STUDY SITE}

The horseshoe-shaped escarpment of Creux du Van is situated in the Jura Mountains near the city of Neuchâtel in western Switzerland at $1170-1450 \mathrm{~m}$ elevation $\left(46^{\circ} 56^{\prime} \mathrm{N}, 6^{\circ} 44^{\prime} \mathrm{E}\right)$ and has a diameter of ca. $1 \mathrm{~km}$. The lower half of the $280 \mathrm{~m}$ altitudinal range is formed by scree slopes and block fields; the upper half forms a vertical calcareous escarpment open to east-northeast. According to 3 year data from the central lower part (at $1200 \mathrm{~m}$ ) of the "amphitheater" by Delaloye et al. (2003), mean annual precipitation is $1600 \mathrm{~mm}$ and mean annual air temperature is $+5.5^{\circ} \mathrm{C}$ (the absolute minimum/maximum air temperatures during that period were $-15.9 /+30.1^{\circ} \mathrm{C}$ ). The ca. 5 months growing season lasts from mid-May to late September. The ground is 


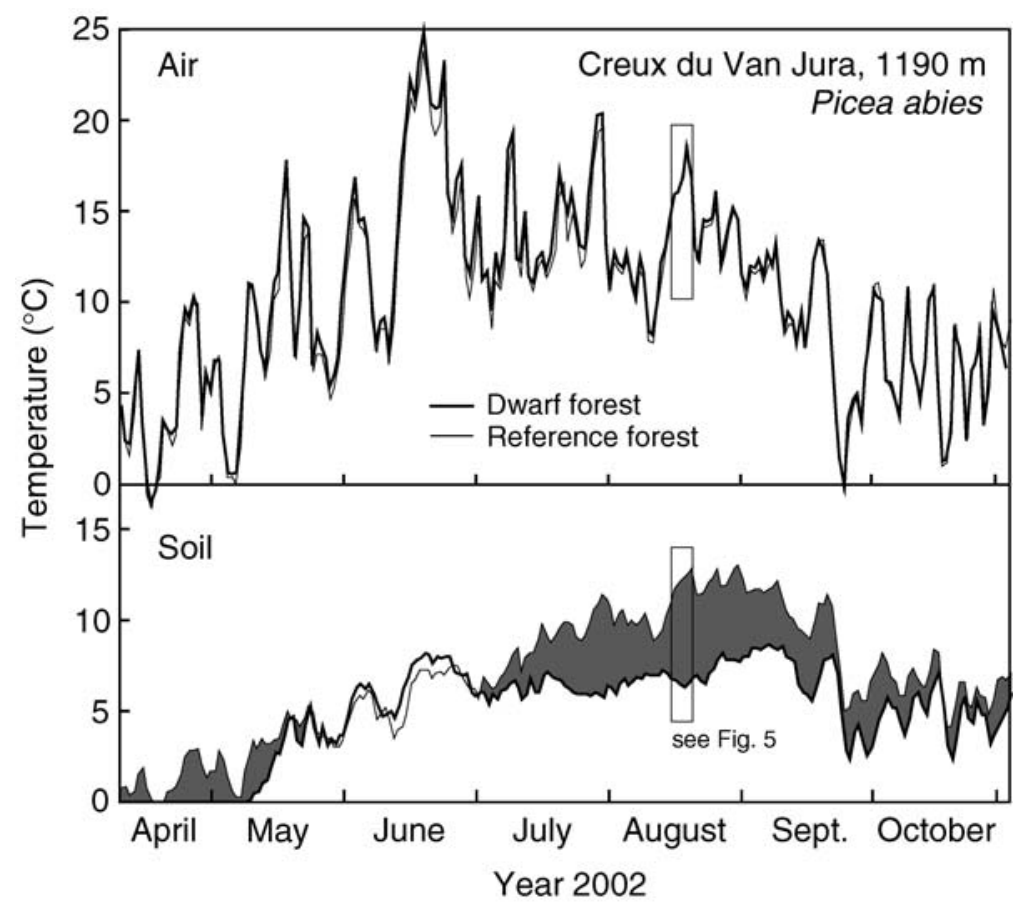

FIGURE 3. Annual course of air and ground temperature $(10$ cm depth) at the Creux du Van dwarf tree location and a nearby reference spruce forest.

under snow cover for ca. 4 months. The typical mean daily global radiation for June and July is $15 \mathrm{MJ} \mathrm{m}^{-2} \mathrm{~d}^{-1}$. At lower solar angles, however, only $1 \mathrm{MJ} \mathrm{m}^{-2} \mathrm{~d}^{-1}$ is measured, primarily because of the shade by the escarpment (November to February), with still only 2-3 $\mathrm{MJ} \mathrm{m}^{-2} \mathrm{~d}^{-1}$ in the transition period (March and October; Delaloye and Reynard, 2001).

The rim of the escarpment $(1450 \mathrm{~m})$ is well below the potential treeline, which would theoretically be at around 1800-1900 m, but the Jura mountains are not high enough to permit the formation of a climatic treeline, which is free from any summit effects (highest peaks are between 1600 and $1700 \mathrm{~m}$ ). The study sites at ca. $1200 \mathrm{~m}$ elevation are close to the montane transition from deciduous beech (Fagus sylvatica) forest to evergreen conifer-dominated forest. The biogeographic situation would best be described as mid-montane and a climate optimal for the growth of Norway spruce (Picea abies). Soils in the whole area (dwarf forest as well as reference forest) are derived from Jurassic calcareous scree, permanently eroding from the escarpment; hence, their texture is disturbed. Soil profiles come closest to a rendzina type. In the dwarf tree stands, raw humus is overlaying blockfields, with pockets of (sphagnum) peat accumulating in the gaps between boulders.

\section{TEMPERATURE MEASUREMENTS}

\section{Long-term Records}

We collected temperature data in a way fully compatible with the protocol used for the global treeline temperature assessment by Körner and Paulsen (2004). Sealed 1 channel miniature data loggers (Tidbit, -30 to $+70 \pm 0.2^{\circ} \mathrm{C}$ resolution; Onset Computer Corporation, Cape Cod, Massachusetts, U.S.A.) were placed at two locations in the soil at $10 \mathrm{~cm}$ depth and in the tree canopy, and readings were taken at hourly intervals for one year (November 2000 to November 2001). Following the detailed analysis presented in Körner and Paulsen (2004), such soil temperatures are best recorded from flat microhabitats under complete screening from any direct solar radiation, e.g., under trees. A homogeneous, reasonably deep substrate at the measurement point was a further criterion. With four criteria (flat, shaded, homogeneous soil, and $10 \mathrm{~cm}$ depth of sensor), temperatures are readily comparable over larger regions without the risk of capturing microhabitat artifacts (Körner and Paulsen, 2004). Hence, readings were taken away from any vents in the block field. Canopy temperatures were recorded on the north side of tree stems in the shade of a dense cover of green shoots. In the dwarfed spruce site this was ca. $2 \mathrm{~m}$ above ground (trees are not much higher than $3 \mathrm{~m}$ ); in the reference forest this was at ca. $8 \mathrm{~m}$ height in the lower canopy (trees are ca. 18-25 m high). We address temperatures by ${ }^{\circ} \mathrm{C}$ and temperature differences by $\mathrm{K}$ to avoid confusion of the two and conform with conventions in physics.

\section{Short-term Records}

In order to assess the spatial patterns of ground temperature we selected a clear mid-summer day (18 July 2003) and screened $10 \mathrm{~cm}$ soil temperatures manually in many locations with a thermistor in a $3 \mathrm{~mm}$ steel probe (Testoterm 110, Testoterm, Lenzkirch, Germany) along a ca. $200 \mathrm{~m}$ transect across both dwarfed and reference tree stands. In addition we explored effects of microtopography and soil depth on temperature by a few hand measurements on the same date using the mobile probe.

\section{TREE STUDIES}

We measured annual length increments over the past 5 years in major unshaded lateral branches. We took 5-mm-diameter increment stem cores (at $30 \mathrm{~cm}$ above ground in dwarf trees and $1.3 \mathrm{~m}$ height in reference trees) and determined tree age at coring height, mean annual radial increment, and present chronologies of actual data (no detrending). Given that the growth differences were obvious and so large, we restricted coring to four representative individuals. The differences were tested for significance with a t-test.

\section{Results}

\section{LONG-TERM TEMPERATURES}

Air/shoot temperatures were very similar in dwarf trees and the reference forest stand throughout the year (Figs. 3 and 4) except for 


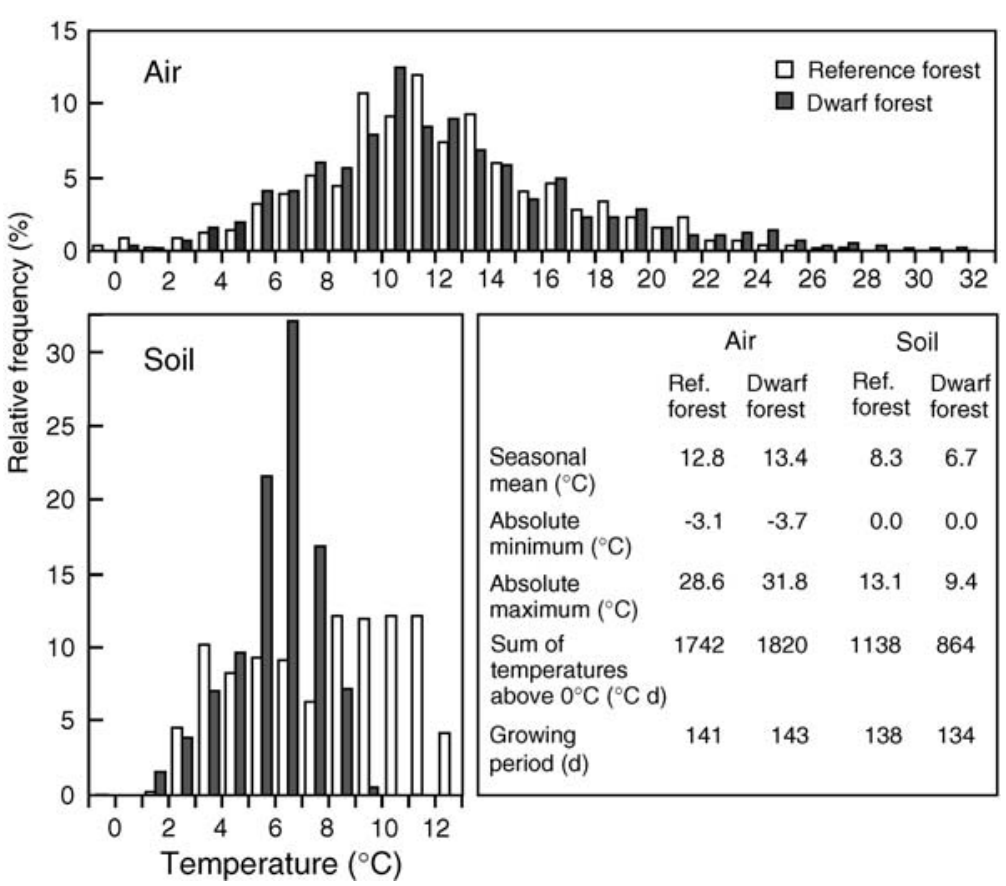

FIGURE 4. Statistical data on air and ground temperatures for the reference forest and the dwarf tree stand. Frequency distributions, seasonal means, and degree hours are for the growing period only. The growing period is defined as the period between the last and the first day when the $-10 \mathrm{~cm}$ soil temperature passes a daily mean of $3.2^{\circ} \mathrm{C}$ ("soil season") or a daily mean of air temperature of $0^{\circ} \mathrm{C}$ ("air season"). At the high elevation climatic treeline, the two fall together (Körner and Paulsen, 2004). For consistency reasons we used these criteria also here, which led to a small discrepancy between soil and air season, which we do not consider important. In the forest the "air season" is 2 days longer than the "soil season", and the difference is 9 days in dwarf trees, because the air warms up faster. hot summer days, when dwarf trees experience significantly higher temperatures (up to $+5 \mathrm{~K}$ at noon) than reference trees, as can be seen for mid-August in Figure 5. Soil temperatures, however, were substantially colder under dwarf trees, except during a transition period from mid-May to June and during a couple of days in autumn. During winter, soils under dwarf trees were about $2-3 \mathrm{~K}$ colder than under the reference forest canopy, which may also be related to radiative cooling in the more open dwarf tree stand.

Applying the threshold temperature of $3.2^{\circ} \mathrm{C}$ in $10 \mathrm{~cm}$ soil depth for the beginning and end of the growing season (corresponding to a daily mean air temperature of $0^{\circ} \mathrm{C}$ ), as suggested by Körner and Paulsen (2004), yields a ca. 130 day growing period (10 May to 20 September). During this period the mean ground temperature under dwarf trees reaches $6.7^{\circ} \mathrm{C}$, exactly the worldwide seasonal mean for high altitude treelines. The thermal difference between dwarf and reference forest stands occurs mainly during the period between midJuly and mid September. So, despite warmer air temperature and a very

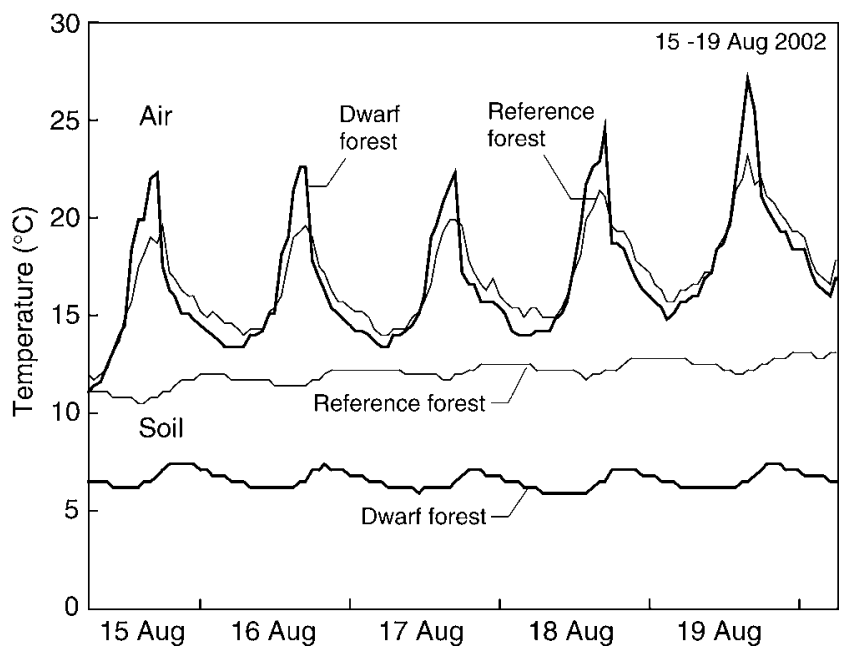

FIGURE 5. Diurnal courses of air and soil temperatures during warm weather in mid-August 2002 (see the boxed period in Fig. 3). open canopy, soils are much colder under dwarf trees than under reference trees during the hottest part of the year.

\section{SHORT-TERM TEMPERATURE DATA}

The data collected manually along the ca. $200 \mathrm{~m}$ horizontal transect within an hour during a bright morning reinforces the results of the long term measurements (Fig. 6): dwarf forest soils exhibit temperatures of close to $6^{\circ} \mathrm{C}$ (range 4.3 to $7.2^{\circ} \mathrm{C}$ ), compared to the reference forest at ca. 8 to $12^{\circ} \mathrm{C}$. All these readings were taken on nearly flat spots in the otherwise rough terrain. A few comparisons between the north vs. south side, or top versus bottom, of hummocks illustrate a strong effect of microtopography, not captured by the standard protocol measurements (Fig. 7). Differences over a distance of less than $1 \mathrm{~m}$ can reach $5 \mathrm{~K}$, which must have significant effects on vegetation. Temperature also declines rapidly with soil depth in the dwarf tree zone, dropping to $2.5^{\circ} \mathrm{C}$ at $40 \mathrm{~cm}$ depth in mid-summer, similar to the readings obtained at only $10 \mathrm{~cm}$ depth in deep gaps between boulders and hummocks.

\section{TREE DATA}

Although the size of the dwarf trees is hardly more than $3 \mathrm{~m}$, they are of similar age to the adjacent 20- to 25-m-tall reference forest trees, both averaging 100-130 years old (Fig. 8). This is close to the age at which trees are normally harvested at this elevation and is about half of the average natural life cycle of spruce. The mean tree-ring width is $0.3 \mathrm{~mm}$ in dwarf trees and $1.1 \mathrm{~mm}$ in reference spruce trees. Shoots of dwarf trees show less than half the annual length increment of reference forest trees (Figs. 1 and 9). The chronologies presented in Figure 8 illustrate that this difference persisted over the last 100 years. The few sharp excursions, particularly in the dwarf trees (e.g., between 1933 and 1934, and 1980 and 1982) match with higher values in reference trees, but we found no explanations for these spikes in climate data or comparative tree ring chronologies for spruce from western Switzerland (F. Meyer, personal communication). The particularly pronounced peaks in dwarf trees in the early 1980s could also reflect so-called reaction wood at coring height (asymmetric, 
FIGURE 6. The spatial variability of $10 \mathrm{~cm}$ depth soil temperature across a $200 \mathrm{~m}$ east-west transect across dwarf tree and reference forest stands (manual measurements). Readings were taken from east to west and then backwards from west to east within $50 \mathrm{~min}$, a period during which air temperature increased from 12.4 to $15^{\circ} \mathrm{C}$.

exaggerating growth in response to mechanical strain). A wider sample that we did not dare to take because of the precious location could illuminate this phenomenon. For the current purpose it is sufficient to document the relatively high age and slow growth of the dwarfed trees.

\section{Discussion}

Our first hypothesis was clearly supported by this assessment, showing that the root zone temperatures at these marginal life conditions for spruce almost exactly match the seasonal mean root zone temperatures at treeline worldwide and those measured in the Alps $100 \mathrm{~km}$ south of this study site in particular (Körner and Pausen, 2004). In stark contrast to soils, the Creux du Van "amphitheater" has a hot microclimate in summer in terms of air temperature, with noon temperatures even substantially higher than in the adjacent reference forest. In other words, the stunted growth of these trees is associated with ground conditions. Since by all standards, the place is wet, it can only be temperature or its influence on nutrition which dwarfs the trees. By taking bi-weekly manual temperature readings during morning hours, Richard (1961) arrived at similar low soil temperatures (at $5 \mathrm{~cm}$ depth) for the dwarf tree site during the season, averaging at $5.3^{\circ} \mathrm{C}$ for the period 15 May to 15 October 1958 (air temperatures, $16.8^{\circ} \mathrm{C}$ ).

Had we collected only long-term records of temperatures following our standard protocol adopted from previous treeline studies, the actual spatial variation in this peculiar habitat would have escaped our attention. The very short distances across which temperatures may vary by several $\mathrm{K}$ across hummocks or boulders (a 5-8 K range was reported by Kajimoto et al., 1998, for similar conditions in Siberia) may permit tree roots to grow into warm spots, but the number (area) of such patches is very restricted and the substrate is commonly thin at all convex structures. It would be interesting to explore the spatial rooting pattern. A plausible assumption is that roots may escape the very cold microsites near vents (temperatures as low as $2.5^{\circ} \mathrm{C}$ ) and avoid exposed tops of boulders, and hence be located largely in those slightly elevated parts of the microtopography where the substrate is still thick enough but not colder than $5^{\circ} \mathrm{C}$ for most of the season. If such foraging for warm spots does occur, it clearly does not permit those trees to escape massive dwarfing and there is no indication that favorable shoot temperatures can ameliorate the "cold feet" syndrome (our second hypothesis). At scales of a few dozens of meters, such slope effects are known to exert massive thermal influences on seedling establishment and sapling growth at treeline (Turner et al., 1982).
The low rates of shoot and radial stem growth are typical for the upper elevational edge of tree occurrence at the natural climatic treeline, with one major difference: Recent decades have caused substantial stimulation of growth at the alpine treeline, presumably because of warmer temperatures (Rolland et al., 1998; Paulsen et al., 2000), contrary with the thermal trend in soil temperatures of the dwarf spruce zone at Creux du Van, where convective cooling is enhanced at high ambient temperatures. The Creux du Van dwarf spruce tree-ring chronology shows very small and invariant $(0.3 \mathrm{~mm})$ radial growth with a few unexplained spikes. Since similar periodic increases in the 1980s had been observed independently in other trees at this site (Schudel, 2002) the formation of so-called reaction wood is an unlikely explanation.

As is often the case, this study raised more questions than it started with. However, it clearly documented an overarching effect of soil temperature on tree development, irrespective of the detailed mechanisms involved. It would be exciting to find an area at the polar or Arctic climatic treeline, where above-ground temperatures are very cold, but ground temperatures are elevated by geothermal effects. Our prediction would be that trees would remain dwarfed, irrespective of ground temperature, because shoot meristems would be affected directly by the low air temperature in the same way as root meristems are affected in cold soil. Chapin (1981) explored growth responses in Carex aquatilis on wet permafrost vs. hot spring habitats, and plants did not do much better near hot springs because soil phosphate status was more important than soil temperature in this specific environment. Sveinbjörnsson (1993) concluded that in Betula pubescens $\mathrm{N}$ availability was more important than soil temperature, in large part due to slow mineralization and $\mathrm{N}$ availability. Karlsson and Nordell (1996), however, concluded from a factorial temperature $\times$ nitrogen addition experiment, also with Betula pubescens seedlings in arcticalpine Scandinavia, that $\mathrm{N}$ uptake is critical at the marginal temperatures near treeline. They found no net growth or nutrient uptake at $5^{\circ} \mathrm{C}$. Accordingly, Weih and Karlsson (2001) observed that a change in soil temperature (in the critical range) affected root $\mathrm{N}$ uptake rate and plant $\mathrm{N}$ concentration in Betula seedlings, similar to the effect of a change in nutrient supply. As soon as temperature increases above a lower threshold in ground temperature as in the upper montane or boreal forests at a substantial distance from the thermal tree limit, soil nutrition can exert an overarching effect (Jarvis and Linder, 2000). For pine seedlings grown in different ground temperatures (Iivonen et al., 1999), nutrient addition only became effective once soil temperatures were higher than $13^{\circ} \mathrm{C}$, a situation almost nonexistent at treeline conditions. From these various tests it seems that it is the thermal

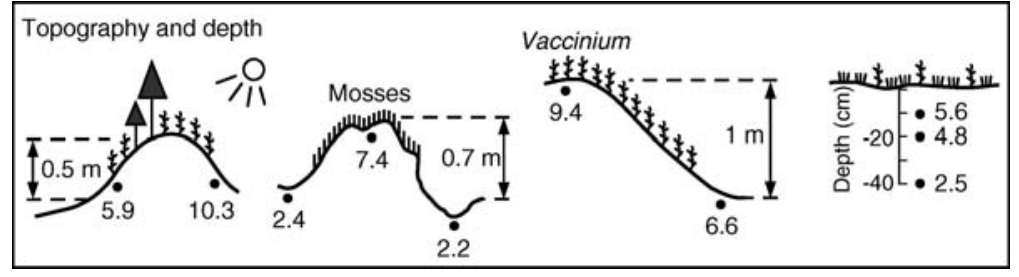

FIGURE 7. The effect of microtopography (hummocks, peat covered rocks) and depth on ground temperature in the dwarf tree zone on a hot summer day (18 July 2003). 


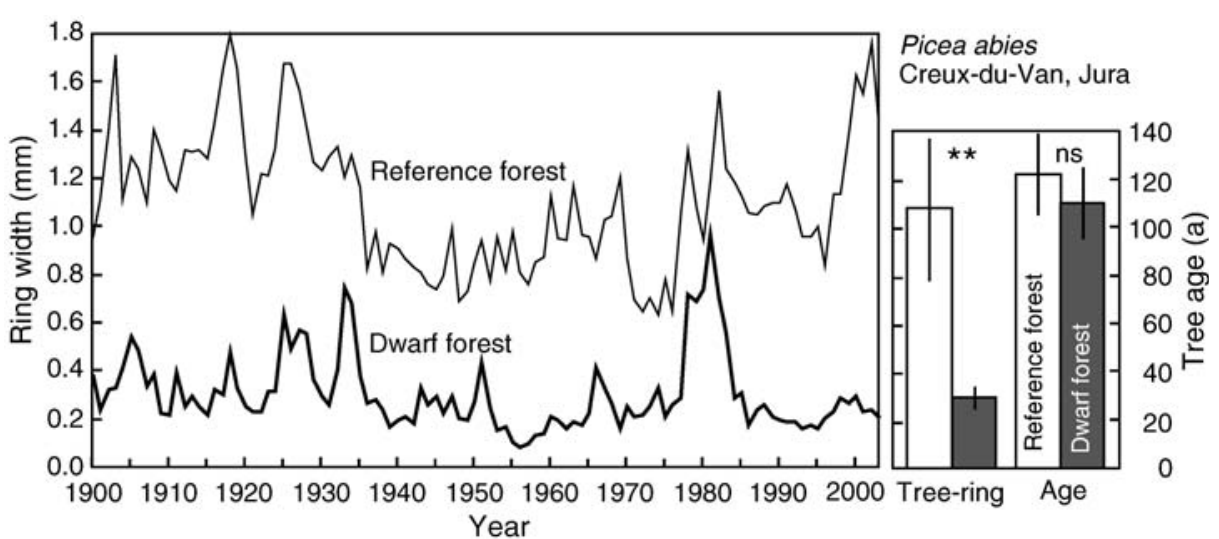

FIGURE 8. Mean tree ring width ( $n=4$ trees) for the past 100 years in dwarfed and reference spruce. Note the similar age (right diagram) of trees, despite a tree height of 2-3 m vs. 18-25 $m$ at this montane location. Climate provides no explanation for the various peaks (see the text). limitation of plant metabolism rather than the availability of nutrients in the substrate, which matters at treeline soil temperatures.

"Nature's experiments" such as this one always have advantages and shortcomings compared to designed experiments. A major advantage is the $>100$ year "experimental" duration and natural life conditions. It will require some manipulative tests to explore the way temperature acts as a dwarfing agent in this case. The provision of nutrients, for instance, could perhaps compensate temperature-driven shortages of $\mathrm{N}$ availability but it would not affect the thermal limitation of uptake. However, nutrient addition commonly affects mycorrhiza and this site has already received substantial atmospheric $\mathrm{N}$ deposition (ca. 15-16 kg N ha ${ }^{-1} \mathrm{a}^{-1}$; B. Rihm, personal communication) for several decades, which is three times the commonly assumed annual requirement to substitute losses in fully grown forests.

Although we cannot definitely exclude $\mathrm{N}$ limitation, it seems highly unlikely that such extreme growth restrictions can be attributed to $\mathrm{N}$, particularly since a small survey of total $\mathrm{N}$ concentrations in spruce needles and sapwood at Creux du Van indicated no difference between dwarf and reference trees ( $\mathrm{G}$. Hoch, unpublished data). $\mathrm{P}$ is a more likely candidate, but the soil chemistry inside and outside the dwarf zone is almost identical and within a few meters at only slightly elevated soil temperatures trees grow tall. A most likely constraint is the metabolism in the root itself (both for nutrient uptake and growth). While a separation of the two seems difficult, a general low temperature limitation of metabolic processes within the plant rather than in the substrate seems the best explanation.

In essence, this study leads us to propose that it is irrelevant whether soil or air temperature is too low, or both. Seasonal mean

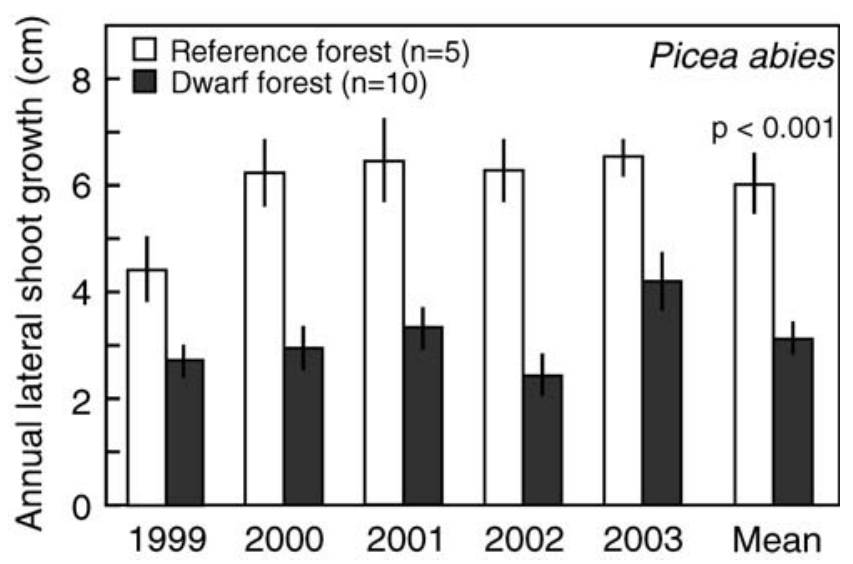

FIGURE 9. The annual length growth of lateral shoots in reference and dwarfed Picea abies trees for 5 years at Creux du Van. temperatures below $6-7^{\circ} \mathrm{C}$ will not permit sufficient meristem activity, and thus tree growth, irrespective of whether root or shoot meristems are affected. All physiological evidence points at close to zero seasonal growth and nutrient uptake below this threshold. Dwarfing in trees growing at this thermal soil environment occurs irrespective of the thermal regime that the shoots are exposed to.

\section{Acknowledgments}

We thank R. Delaloye for sharing then-unpublished experience with us when we started this survey. A. Rist generously provided data from several Swiss permafrost islands, M. Monbaron explained to us the geological history of the site, F. Meyer advised us on tree-ring data, J. Paulsen processed our climatic data, and S. Peláez-Riedl made all the diagrams. We are also grateful to $\mathrm{B}$. Rihm for providing $\mathrm{N}$ deposition estimates from the spatially explicit, high resolution Swiss $\mathrm{N}$ deposition model and to E. Hiltbrunner for arranging this contact and helping with interpretation of $\mathrm{N}$ data. William Bowman (Boulder) kindly helped us with the English editing of our text.

\section{References Cited}

Bonan, G. B., and Shugart, H. H., 1989: Environmental factors and ecological processes in boreal forests. Annual Review of Ecology and Systematics, 20: 1-28.

Canaval, R., 1893: Ein Eiskeller in den Karawanken. Carinthia II (Klagenfurt), 83: 178-180.

Chapin, F. S., III, 1981: Field measurements of growth and phosphate absorption in Carex aquatilis along a latitudinal gradient. Arctic and Alpine Research, 13: 83-94.

Däniker, A., 1923: Biologische Studien über Baum- und Waldgrenze, insbesondere über die klimatischen Ursachen und deren Zusammenhänge. Vierteljahresschrift der Naturforschenden Gesellschaft Zürich, 68: 1-102.

Delaloye, R., and Reynard, E., 2001: Les eboulis gelés du Creux du Van (Chaine du Jura, Suisse). Environnements périglaciaires, 8: 118-129.

Delaloye, R., Reynard, E., Lambiel, C., Marescot, L., and Monnet, R., 2003: Thermal anomaly in a cold scree slope (Creux du Van, Switzerland). In Phillips, M., Springman, S. M., and Arenson, L. U. (eds.), Proceedings 8th Int. Conf. Permafrost, Zurich 2003. Lisse: Balkema AA, 175-180.

Domisch, T., Finer, L., and Lehto, T., 2001: Effects of soil temperature on biomass and carbohydrate allocation in Scots pine (Pinus sylvestris) seedlings at the beginning of the growing season. Tree Physiology, 21: 465-472.

Grace, J., Allen, S. J., and Wilson, C., 1989: Climate and the meristem temperatures of plant communities near the tree-lines. Oecologia, 79: 198-204. 
Häsler, R., Streule, A., and Turner, H., 1999: Shoot and root growth of young Larix decidua in contrasting microenvironments near the alpine timberline. Phyton, 39: 47-52.

Hoch, G., and Körner, Ch., 2003: The carbon charging of pines at the climatic treeline: a global comparison. Oecologia, 135: 10-21.

Hölzel, E., 1963: Tierleben im Eiskeller der Matzen in der Karawankennordkette. Carinthia II (Klagenfurt), 153: 161-187.

Iivonen, S., Rikala, R., Ryyppo, A., and Vapaavuori, E., 1999: Responses of Scots pine (Pinus sylvestris) seedlings grown in different nutrient regimes to changing root zone temperature in spring. Tree Physiology, 19: 951-958.

Jarvis, P., and Linder, S., 2000: Constraints to growth of boreal forests. Nature, 405: 904-905.

Kajimoto, T., Matsuura, Y., Mori, S., Sofronov, M. A., Volokitina, A. V., and Abaimov, A. P., 1998: Root growth of Larix gmelinii and microsite difference in soil-temperature on permafrost soils in central Siberia. In Mori, S., Kanazawa, Y., Matsuura, Y., and Inoue, G. (eds.), Proceedings of the sixth symposium on the joint Siberian permafrost studies between Japan and Russia in 1997. Tsukuba: National Inst. Environmental Studies, 43-51.

Karlsson, P. S., and Nordell, K. O., 1996: Effects of soil temperature on the nitrogen economy and growth of mountain birch seedlings near its presumed low temperature distribution limit. Ecoscience, 3: 183-189.

Körner, Ch., 1998: A re-assessment of high elevation treeline positions and their explanation. Oecologia, 115: 445-459.

Körner, Ch., 2003: Alpine plant life. Second edition. Berlin: Springer Verlag.

Körner, Ch., and Paulsen, J., 2004: A world-wide study of high altitude treeline temperatures. Journal of Biogeography, 31: 713-732.

Molenda, R., and Gude, M., 2000: Naturschutzfachliche Bewertung von Blockhalden mit airconditioning Effekt. Entomologia Basiliensa, 22: 87-91.

Monbaron, M., 1990: Impacts de météorites ou cicatrices d'érosion? Etude de quelques formes en hémicycle du Jura plissé Suisse. Bulletin Société Neuchâteloise des Sciences Naturelles, 113: 145-156.

Paulsen, J., Weber, U. M., and Körner, Ch., 2000: Tree growth near treeline: abrupt or gradual reduction with altitude? Arctic, Antarctic, and Alpine Research, 32: 14-20.

Richard, J-L., 1961: Les forêts acidophiles du Jura-êtude phytosociologique et écologique. Commission Phytogéographique de la Société Helvétique des Sciences Naturelles, Fasc. 38.

Rist, A., 2002: Unterkühlte Blockschutthalden mit HexenwädliAbiotische Faktoren zur Charakterisierung des Phänomens. Diploma Thesis, Technical University of Munich, Germany.
Rolland, C., Petitcolas, V., and Michalet, R., 1998: Changes in radial tree growth for Picea abies, Larix decidua, Pinus cembra, and Pinus uncinata near the alpine timberline since 1750. Trees-Structure and Function, 13: 40-53.

Schindler, H., Kinzel, H., and Burian, K., 1976: Ökophysiologische Untersuchungen an Pflanzen der Matzen-Eisstandorte. Carinthia II (Klagenfurt), 166: 269-307.

Schudel, K., 2002: Hexenwäldli—Dendroökologie von Kümmerfichtenbeständen auf unterkühlten Schutthalden. Diploma Thesis, Swiss Polytechnic University, Zurich, Switzerland.

Scott, P. A., Bentley, C. V., Fayle, D. C. F., and Hansell, R. I. C., 1987: Crown forms and shoot elongation of white spruce at the treeline, Churchill, Manitoba, Canada. Arctic and Alpine Research, 19: 175-186.

Sveinbjörnsson, B., 1993: Climate and growth of mountain birch near the treeline in northern Sweden and Iceland. In Frenzel, B. (ed.), Oscillations of the alpine and polar tree limits in the Holocene. Stuttgart: Gustav Fischer Verlag, 57-67.

Takenaka, A., and Abaimov, A. P., 1998: Analysis of the extension of long shoots within a crown of Larix gmelinii. In Mori, S., Kanazawa, Y., Matsuura, Y., and Inoue, G. (eds.), Proceedings of the sixth symposium on the joint Siberian permafrost studies between Japan and Russia in 1997. Tsukuba: National Inst. Environmental Studies, $31-42$.

Tryon, P. R., and Chapin, F. S., III, 1983: Temperature control over root growth and root biomass in taiga forest trees. Canadian Journal of Forest Research, 13: 827-833.

Turner, H., Häsler, R., and Schönenberger, W., 1982: Contrasting microenvironments and their effects on carbon uptake and allocation by young conifers near alpine treeline in Switzerland. In Waring, R. H. (ed.), Carbon uptake and allocation in subalpine ecosystems as a key to management. Forest Research Laboratory, Oregon State University, 22-30.

Wegmüller, J., and Wegmüller, S., 1985: Ökologische Untersuchungen an Zwergfichtenbeständen im Gebiet des Turnen (Niedersimmental). Mitteilungen der Naturforschenden Gesellschaft Bern N.F., 42.

Weih, M., and Karlsson, P. S., 2001: Growth responses of mountain birch to air and soil temperature: Is increasing leaf-nitrogen content an acclimation to lower air temperature? New Phytologist, 150: $147-155$.

Wilson, C., Grace, J., Allen, S., and Slack, F., 1987: Temperature and stature: a study of temperatures in montane vegetation. Functional Ecology, 1: 405-413.

Revised ms submitted March 2005 